\title{
An agricultural field of Hellenistic date at Pauli Stincus, Terralba, Sardinia
}

\author{
Peter van Dommelen ${ }^{1, *}$, Samantha Lash ${ }^{1}$, Matthew Naglak ${ }^{2}$, \\ Cristiano Nicosia ${ }^{3}$, Guillem Pérez Jordà ${ }^{4} \&$ Damià Ramis $^{5}$
}

Excavation at Pauli Stincus in Sardinia has revealed an ancient plough soil, with associated evidence of intensive prehistoric agricultural activities.

Keywords: Sardinia, Pauli Stincus, Hellenistic period, agriculture

\section{Introduction}

The site of Pauli Stincus is situated in the reclaimed Terralba wetlands on the south-eastern shores of the Gulf of Oristano in west-central Sardinia. The landscape comprises extensive sand dunes that overlie substantial clay deposits, resulting in rapidly draining soils of variable depth over a fertile substratum of fluvial origins. Before reclamation and lowering of the water table, the low-lying dune valleys became marshy during the rainy winter months (Ruiz et al. 2018). In Classical Antiquity, between the fourth century BC and the fifth century AD, the Terralba wetlands were densely settled by farming households that occupied numerous homesteads carefully positioned on dune ridges and higher ground to the east. Two of these farms were excavated in 2007 and 2010 (Figure 1).

\section{Fieldwork at Pauli Stincus}

The toponym Pauli Stincus ('rush bog') refers to the depression at the foot of a sand dune that turned waterlogged when groundwater levels rose in winter. On the top of the dune, the remains of a medium-sized Punic rural settlement were first recorded in the 1990s, and were systematically documented through surface artefact collection and geophysical survey in 2004 (van Dommelen 2006). When the site was excavated in 2010, a narrow trench was dug to explore the extent of the outer farmyard, and to examine the stratigraphic sequence of aeolian and fluvial deposits. This revealed a buried plough soil in the section (Díes Cusí et al. 2011; Nicosia et al. 2013; Figure 2). Augering in later years demonstrated that this buried soil horizon extended over a much larger area, at a depth of approximately $0.6 \mathrm{~m}$ below the modern surface.

1 Joukowsky Institute for Archaeology and the Ancient World, Brown University, Rhode Island Hall, 60 George Street, Providence, RI 02912, USA

2 Interdepartmental Program in Classical Art and Archaeology, University of Michigan, 2160 Angell Hall, 435 State Street, Ann Arbor, MI 48109, USA

3 Dipartimento dei Beni Culturali, Università degli Studi di Padova, Piazza Capitanato 7, 35139 Padova, Italy

4 G.I. Arqueobiología, Instituto de Historia, CSIC, Calle de Albasanz, 26, 28037 Madrid, Spain

5 Independent Researcher, Calle Moragues, 34, 07006 Palma de Mallorca, Mallorca, Spain

* Author for correspondence (Email: peter_van_dommelen@brown.edu)

(C) Antiquity Publications Ltd, 2018 ANTIQUITY 92 365, e7 (2018): 1-8 


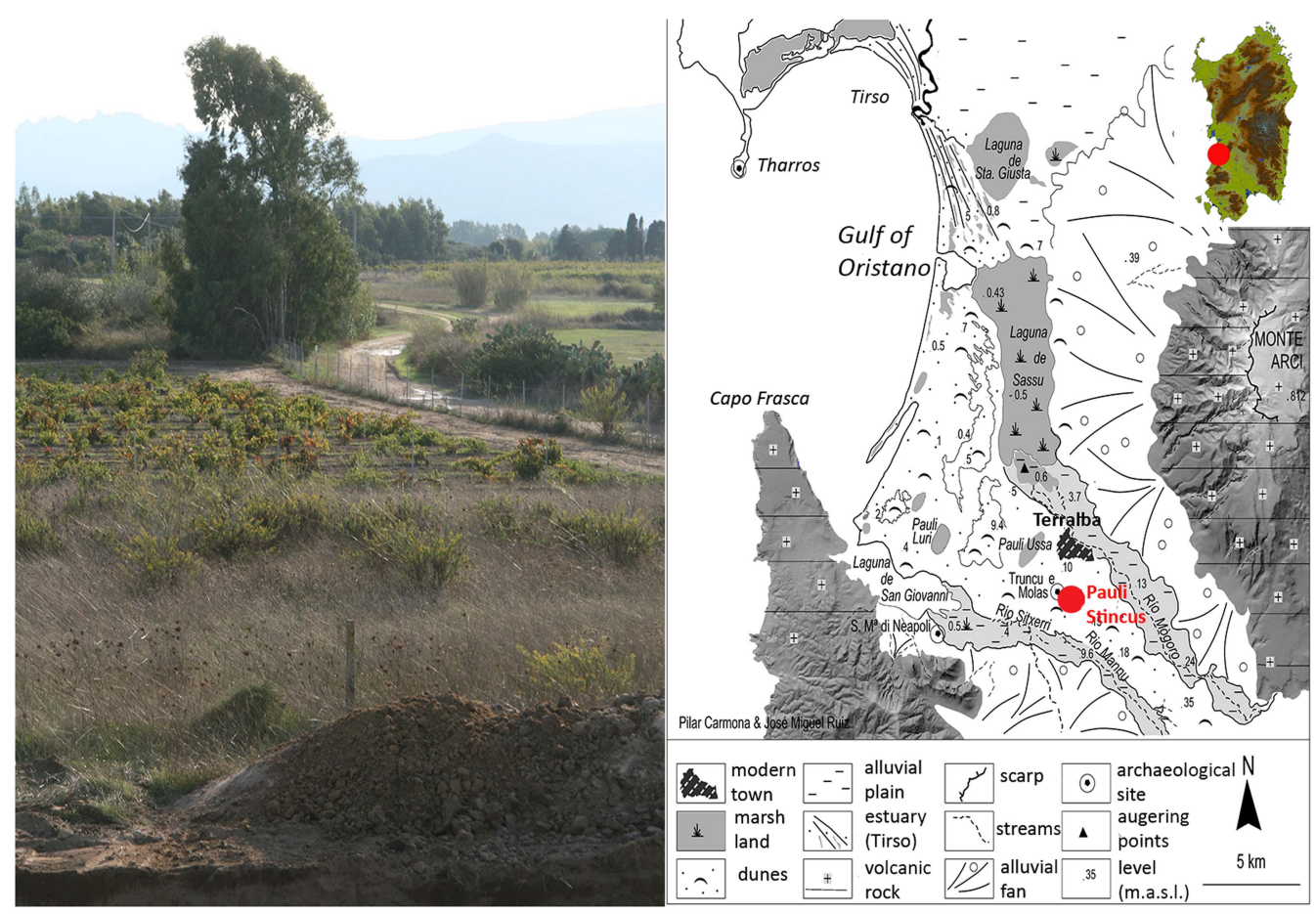

Figure 1. General view of the modern field at Pauli Stincus, and a geomorphological overview map of the Terralba district (photograph by P. van Dommelen; geomorphological map courtesy of J. Ruiz).

The buried plough soil at Pauli Stincus offered a rare opportunity to investigate a Mediterranean agricultural field, very few of which have been excavated extensively (Vera Rodríguez \& Echevarría Sánchez 2013; Arnoldussen \& van der Linden 2017). Furthermore, the direct association with an excavated homestead promised the even more unusual opportunity to contextualise the field in its cultural setting (Figure 2).

We excavated one large (modern) field in October 2017. We began by defining an approximately $250 \mathrm{~m}^{2}$ area that included where augering had shown the ancient plough soil to be present (Figure 2), but that did not substantially overlap with the 2010 excavation. As the depth of the buried soil horizon was already known (Nicosia et al. 2013), the overlying deposits were removed mechanically. Three $1 \mathrm{~m}$-wide south-east- to north-west-running trenches (A-B-C) were mechanically excavated through the ancient plough soil to expose it in section (Figure 3).

\section{Excavating the ancient plough soil}

As the trench sections showed the extent of the ancient plough soil, an area of $20 \times 10 \mathrm{~m}$ was carefully excavated by hand to expose its surface. Although it proved impossible to distinguish a field boundary to the south-west, the general impression was that nevertheless, around trench $\mathrm{B}$, the plough soil was much diminished, perhaps merging with a natural soil horizon. On the western side, the ploughed field was clearly demarcated by a linear greyishblack fill—possibly a backfilled ditch (labelled 2008 in Figure 4). From the sections, it was (C) Antiquity Publications Ltd, 2018 


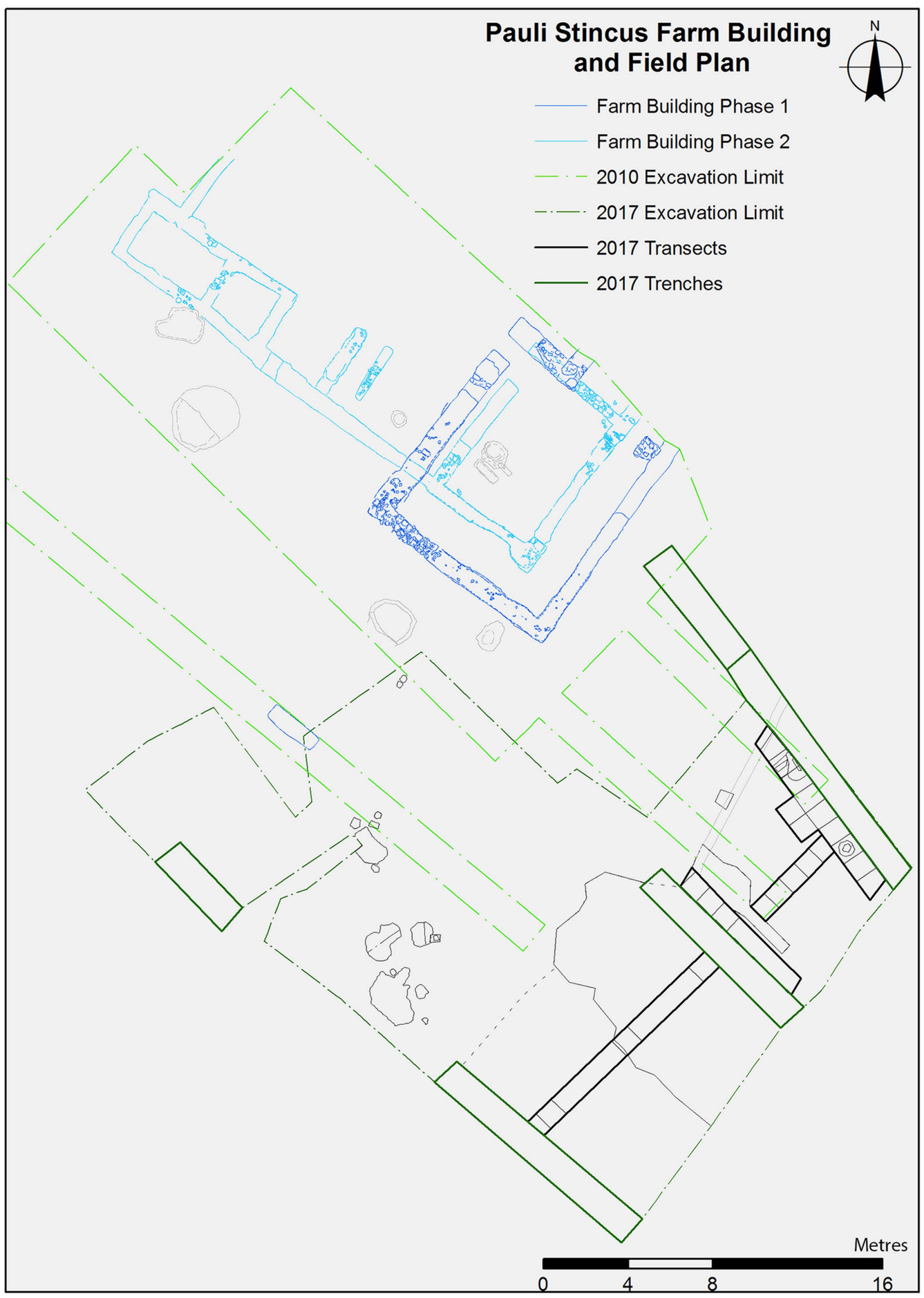

Figure 2. Combined plan of the excavated farmstead (2010) and the agricultural field (2017) at Pauli Stincus (figure by E. Dies Cusi \& M. Naglak).

(C) Antiquity Publications Ltd, 2018 
Peter van Dommelen et al.

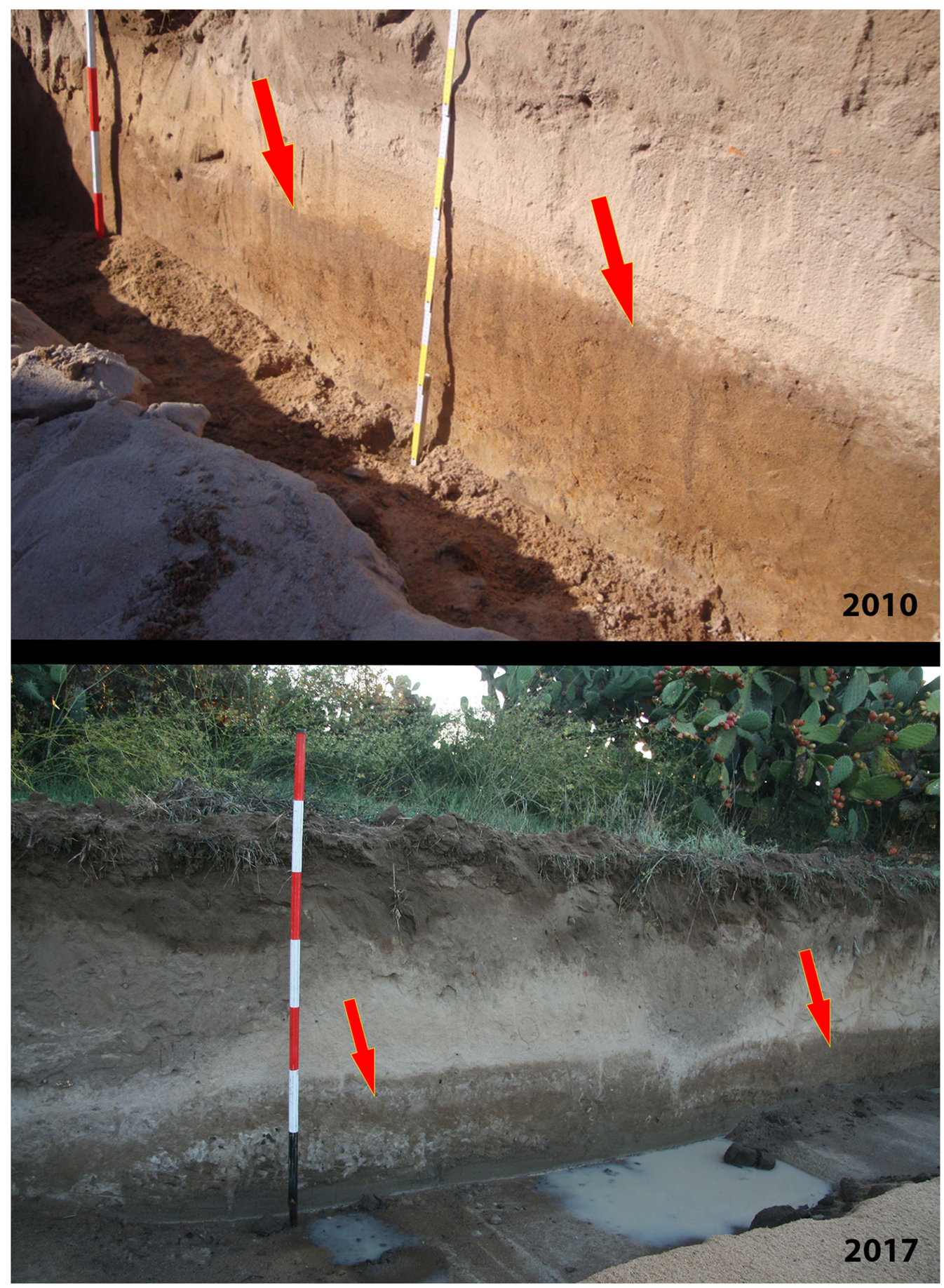

Figure 3. Views of the buried plough soil as documented in 2010 (top), and of the 2017 north-east section of the excavated area (bottom). As highlighted, the plough soil is clearly visible at the base of the sections (photographs by C. Nicosia \& P. van Dommelen).

(C) Antiquity Publications Ltd, 2018 


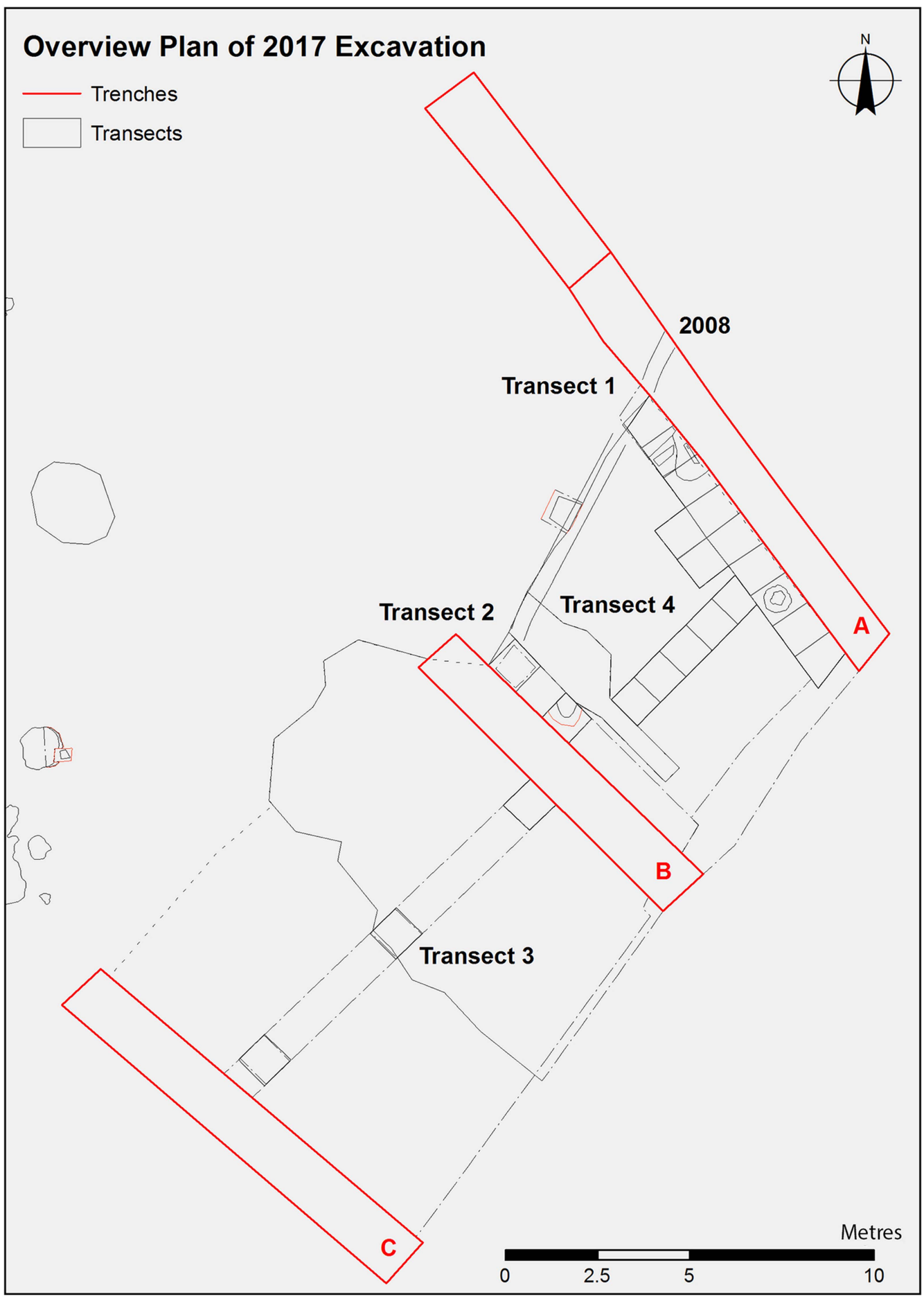

Figure 4. Plan of the 2017 excavated area, including the mechanically excavated trenches (A-B-C) and the transects of hand-excavated squares (1-2-3-4) (figure by M. Naglak).

(C) Antiquity Publications Ltd, 2018 


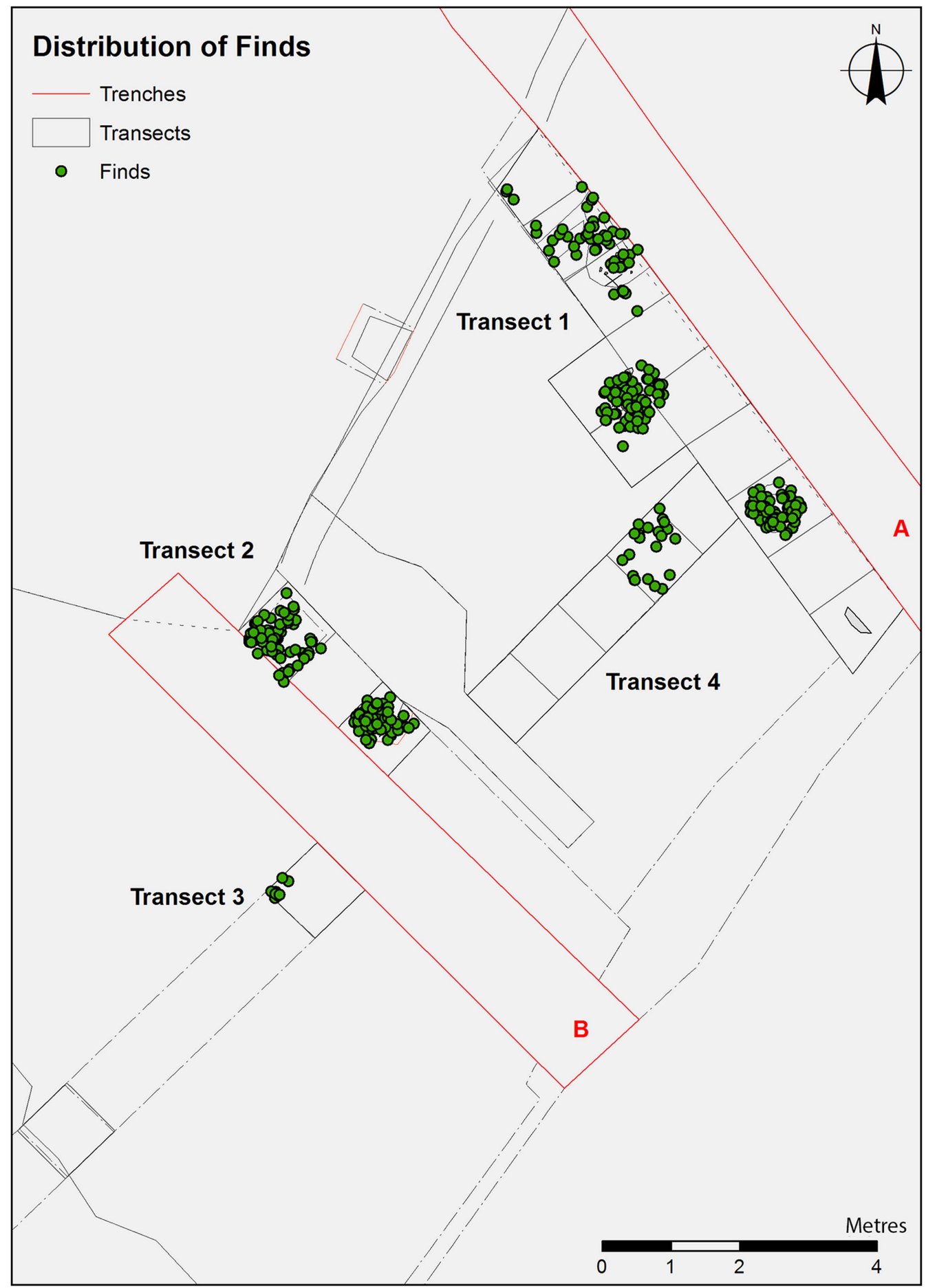

Figure 5. Plan of the 2017 excavated area, showing the distribution of all finds (figure by M. Naglak).

(C) Antiquity Publications Ltd, 2018 

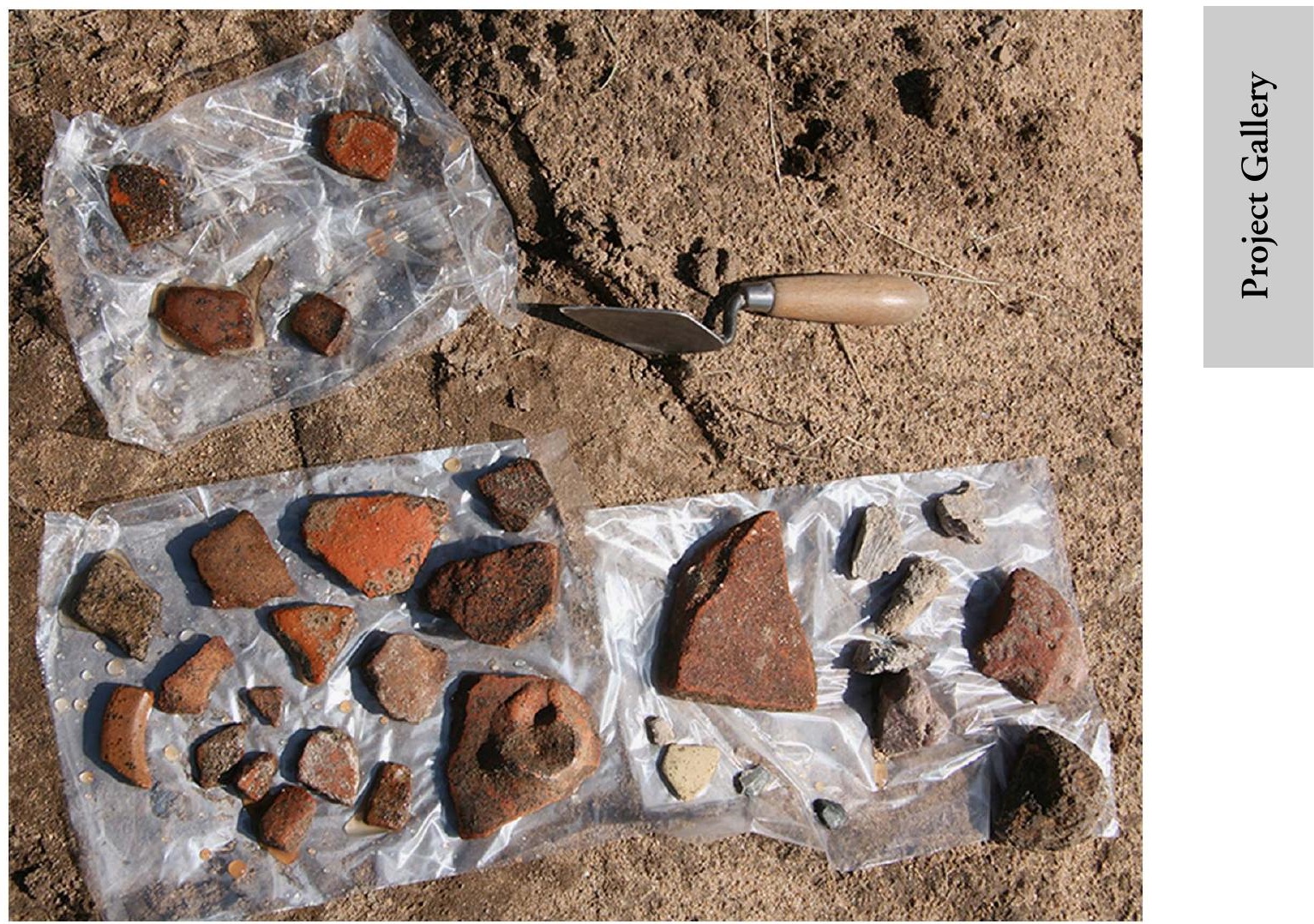

Figure 6. Ceramic finds drying in the field (photograph by P. van Dommelen).

clear that the ancient field continued beyond the excavation area to the north-east and south-east (Figure 4).

Having thus delimited the ancient agricultural field to an approximately $8 \times 9 \mathrm{~m}$ rectangle in the north-west corner of the excavation area, we excavated the plough soil itself by hand in adjoining $1 \times 1 \mathrm{~m}$ squares that lined up in four transects (Figure 4: transects $1-4$ ). We plotted every find, recorded all features, dry-sieved all sediments and wet-sieved 201 samples. Transects 1 and 2 yielded many finds and features, the latter comprising mostly regularly shaped pits. It was also evident that virtually all finds were clustered in the area identified as the agricultural field; our initial interpretation was therefore corroborated (Figure 5). In addition to the flotation samples, five large soil columns were retrieved from the northeastern and south-western sections for thin-section, granulometric and geochemical analyses.

\section{Finds}

In total, 412 ceramic - including 34 diagnostics — and 13 obsidian fragments were recovered, weighing $7.63 \mathrm{~kg}$ in total (Figure 6). The obsidian mostly consists of small flakes. The bulk of the pottery comprises coarse wall fragments, but there are also nine fine ware sherds (Campanian Black Gloss). The fragments suggest a chronology spanning from the third to second centuries BC, 
which coincides with the mid fourth- to late second-century BC occupation of the farmstead. The majority of ceramic finds are in a coarse fabric known as 'Riu Mannu A', which was produced locally between the fifth and first centuries BC (van Dommelen \& Trapichler 2011). The abraded nature of the sherds suggests that they may be regarded as 'off-site' pottery that was spread over the field during manuring. Sherd density may indicate the intensity of use of the field. The various pits imply that the field was in use over a prolonged period.

\section{Conclusions}

While forthcoming analytical results will expand and refine our understanding of this site and Punic agricultural practices, we can already confidently confirm that we have revealed approximately $100 \mathrm{~m}^{2}$ of an ancient, ploughed agricultural field, which was cultivated intensively in the third and second centuries BC.

\section{Acknowledgements}

We gratefully acknowledge the support of Massimo Casagrande, Massimiliano Pilloni and Sandro Perra, without whom the excavation would never have happened. We also thank the regional Soprintendenza and the Italian Ministry of Heritage and Culture for granting permission to excavate. Fieldwork and laboratory analyses are supported by Brown University (IBES-Institute at Brown for Environment and Society) and the Spanish Ministerio de Cultura (grant BBAA2017-2).

\section{References}

Arnoldussen, S. \& M. van der Linden. 2017. Palaeo-ecological and archaeological analysis of two Dutch Celtic fields (Zeijen-Noordse Veld and Wekerom-Lunteren): solving the puzzle of local Celtic field bank formation. Vegetation History and Archaeobotany 26: 551-70. https://doi.org/10.1007/s00334-017-0625-z

Díes Cusí, E., P. van Dommelen \& C. Gómez BeLLARD. 2011. Excavaciones en la granja púnica de Pauli Stincus (Terralba, Cerdeña). Saguntum 42: 123-27.

Nicosia, C., R. Langohr, P. Carmona González, C. Gómez Bellard, E. Modrall, J.M. Ruiz Pérez \& P. van Dommelen. 2013. Land use history and site formation processes at the Punic site of Pauli Stincus in west central Sardinia. Geoarchaeology 28: 373-93. https://doi.org/10.1002/gea.21443

Ruiz, J.M., P. Carmona, C. Gómez Bellard \& P. van Dommelen. 2018. Geomorfología y cambio ambiental en el entorno de los yacimientos púnicos de la llanura de Terralba (Golfo de Oristano, isla de Cerdeña, Italia). Boletín Geológico y Minero 129: 331-52. https://doi.org/10.21701/bolgeomin.129.1.013 van Dommelen, P. 2006. Punic farms and Carthaginian colonists: surveying Punic rural settlement in the Central Mediterranean. Journal of Roman Archaeology 19: 7-28. https://doi.org/10.1017/S1047759400006243

van Dommelen, P. \& M. Trapichler. 2011. Fabrics of western central Sardinia, in V. Gassner (ed.) Fabrics of the Central Mediterranean: provenance studies on pottery in the southern Central Mediterranean from the $6^{\text {th }}$ to the $2^{\text {nd }}$ c. B.C.: Available at: http://facem.at/project/papers.php (accessed 20 September 2018).

Vera Rodríguez, J.C. \& A. Echevarría Sánchez. 2013. Sistemas agrícolas del I milenio a.C. en el yacimiento de La Orden-Seminario de Huelva. Viticultura protohistórica a partir del análisis arqueológico de las huellas de cultivo, in S. Celestino Pérez \& J. Blánquez Pérez (ed.) Patrimonio cultural de la vid y el vino [Vine and wine cultural heritage]: 95-106. Madrid: UAM Ediciones. 